\title{
\begin{tabular}{l|cc} 
Media & p-ISSN $1979-3693$ & e-ISSN 2477 - 0647 \\
Statisti1Ka & MEDIA STATISTIKA 9(1) 2016: 63-73 \\
http://ejournal.undip.ac.id/index.php/media_statistika
\end{tabular}
}

\section{PEMODELAN GRAFIK PENGENDALI TOTAL DAN RATAAN DISKRIT UNTUK GENERALISASI DISTRIBUSI GEOMETRIK}

\author{
Sudarno ${ }^{1}$, Moch. Abdul Mukid ${ }^{2}$ \\ ${ }^{1,2}$ Departemen Statistika FSM UNDIP \\ 1email: dsghani@gmail.com \\ ${ }^{2}$ email: mamukid@yahoo.com
}

DOI: 10.14710/medstat.9.1.63-73

\begin{abstract}
Total events which do by counting will be obtained discret data type. The discret data type and geometric distribution could be drawn by total number of events chart ( $\mathrm{G}$ chart) and average number of event chart (H chart). In this research result upper control limit, center line, and lower control limit, both $\mathrm{G}$ chart and $\mathrm{H}$ chart. Data processing of the case, resulting $\mathrm{G}$ chart that upper control limit is 80.77 and center line is 39.8 , meanwhile by $\mathrm{H}$ chart obtained that upper control limit and center line, respectively, 11.54 and 5.8. The results of $\mathrm{G}$ chart and $\mathrm{H}$ chart could be used for prediction events at the future to anticipate the real problems. Therefore, the systems have no problem and their activities will be dynamic, stable and best perform.
\end{abstract}

Keywords:Geometric Distribution, Total Number of Event Chart, Average Number of Event Chart

\section{PENDAHULUAN}

Kejadian yang muncul pada proses produksi ternyata menghasilkan kuantitas dan kualitas yang tidak selalu sama. Walaupun dalam perlakuannya dibuat sehomogin mungkin. Misalkan pada pembuatan mie instan, walaupun sudah direncanakan dengan sebaik mungkin di bagian peralatan, bahan dan operator. Ternyata masih terjadi perbedaan hasil produk yang berupa warna, berat dan kekeringannya. Untuk mengetahui perbedaan atau perubahan nilai yang muncul dapat menggunakan bantuan berdasarkan grafik pengendalian kualitas. Secara umum, grafik pengendalian kualitas dapat dikelompokkan kedalam dua jenis, yaitu grafik pengendali variabel dan grafik pengendali atribut. Grafik pengendali variabel mengamati karakteristik kualitas dalam bentuk variabel yang diukur menurut skala kontinu. Nilai dari kharakteristik kualitas diperoleh dengan cara mengukur atau menimbang. Sedangkan Grafik pengendali atribut mengamati karakteristik kualitas dalam bentuk atribut (tanda) yang diukur menurut skala diskrit. Nilai dari kharakteristik kualitas diperoleh dengan cara menghitung (Mitra, 1993 dan Montgomery, 2013).

Dalam membuat grafik pengendali kualitas terdapat beberapa hal yang perlu diperhatikan, yaitu ukuran sampel, batas kendali, frekuensi sampling dan jumlah atau banyaknya sampel. Ukuran sampel merupakan banyaknya anggota sampel yang diambil. Jumlahnya dapat konstan dan boleh juga bervariabel. Batas kendali berupa batas kendali atas (BKA), garis tengah (GT) dan batas kendali bawah (BKB). Frekuensi sampling merupakan periode atau seringnya waktu pengambilan sampel. Sedangkan banyaknya sampel merupakan jumlah sampel yang terpilih. Biasanya grafik pengendali kualitas 
berdasarkan grafik pengendali Shewhart. Perumusan grafik pengendalinya dapat dinyatakan sebagai berikut:

Misalkan $w$ merupakan statistik sampel dari karakteristik kualitas yang diselidiki. Andaikan rataan $w$ adalah $\mu_{w}$ dan simpangan baku wadalah $\sigma_{w}$, maka batas kendalinya dirumuskan

$$
\begin{aligned}
& \mathrm{BKA}=\mu_{\mathrm{w}}+\mathrm{L} \sigma_{\mathrm{w}} \\
& \mathrm{GT}=\mu_{\mathrm{w}} \\
& \mathrm{BKB}=\mu_{\mathrm{w}}-\mathrm{L} \sigma_{\mathrm{w}}
\end{aligned}
$$

dengan L adalah jarak batas pengendali dari GT, yang dinyatakan dalam satuan simpangan baku(Mitra, 1993 dan Montgomery, 2013).

Variabilitas yang muncul pada kejadian atau produk perlu diukur tingkat deviasinya terhadap batas ambangnya. Misalkan untuk mengukur kuantitas keragaman produk, dapat menggunakan grafik pengendali ragam. Pada Sudarno (2014) menyatakan bahwa grafik pegendali ragam akan dihasilkan batas kendali atas, garis tengah dan batas kendali bawah dari keragaman sampel yang dipelajari. Apakah nilai keragamannya masih di dalam batas ambang atau tidak. Sehingga dalam kondisi ini dapat diambil keputusan untuk bertindak demi kebaikan proses atau produk yang dihasilkan. Selanjutnya dalam Wu et al. (2009), mengusulkan grafik $n p_{\mathrm{x}}$ untuk memonitor rataan proses dengan pengawasan berbentuk atribut sebagai alternatif menggunakan grafik $\bar{x}$. Sedangkan Ho et al. (2013) berpendapat yang lebih luas bahwa untuk memonitor variabilitas proses pada grafik pengendali jenis atribut menggunakan grafik $n p_{\mathrm{s}}^{2}$.

Untuk karakteristik mutu yang berupa atribut dengan kategorik cacat biasanya diukur dengan grafik pengendali jumlah cacat atau grafik $c$. Kuantitas jumlah cacat diasumsikan berdistribusi Poisson. Hal yang menarik dari distribusi Poisson adalah rataan sama dengan ragamnya, untuk variabel acaknya. Selain itu nilai terkecil dari variabel acak yang diselidiki dapat bernilai nol atau tidak ada. Tetapi dalam kejadian nyata sifat-sifat di atas sulit untuk dipenuhi, maksudnya jarang ada nilai rataan sama dengan ragam dari variabel acaknya. Selain itu kejadian dengan nilai nol adalah tidak menarik, dianggap tidak bekerja atau tidak produktif. Sehingga diperlukan konsep statistika yang lain yaitu distribusi dari variable acak mempunyai nilai rataan yang berbeda dengan nilai ragamnya dan nilai terkecil yang mungkin dari variabel acaknya tidak sama dengan nol. Distribusi variabel acak yang memenuhi syarat tersebut adalah distribusi geometrik. Dalam distribusi geometrik bahwa rataan dari variabel acaknya berbeda dengan ragamnya dan nilai terkecil dari variabel acaknya adalah 1 . Karena angka 1 merupakan satuan atau faktor dari semua bilangan bulat, maka konsep yang ada pada distribusi geometrik boleh diterapkan pada kejadian yang datanya berbasis distribusi geometric (Bain, 1992 dan Montgomery, 2013).

Pada penelitian ini akan diamati kejadian bersifat diskrit dengan variabel acak berupa total jumlah kejadian (T) dan rataan jumlah kejadian $(\bar{x})$. Untuk total jumlah kejadian merupakan jumlah seluruh kejadian yang muncul. Variabel acak $\mathrm{T}$ akan dicari rataan dan ragamnya. Berdasarkan hasil rataan dan ragam serta konsep grafik pengendali Shewhart dapat dikontruksi rumus untuk batas kendali atas, garis tengah dan batas kendali bawah. Sehingga dapat dihasilkan grafik pengendali T yang disebut grafik G. Demikian pula untuk rataan jumlah kejadian merupakan rata-rata dari semua kejadian yang muncul. Selanjutnya akan dicari rataan dan ragam dari variabel acak $\bar{x}$. Berdasarkan hasil rataan dan ragam serta konsep grafik pengendali Shewhart dapat dibuat rumus untuk batas kendali atas, garis tengah dan batas kendali bawah. Sehingga dapat dihasilkan grafik pengendali $\bar{x}$ untuk variabel acak diskrit yang disebut grafik $\mathrm{H}$. Hasil utama yang diperoleh dari pengolahan menggunakan grafik $\mathrm{G}$ dan grafik $\mathrm{H}$ adalah distribusi atau proses baik total jumlah 
kejadian maupun rataan jumlah kejadian apakah di dalam batas ambang atau tidak. Selain itu dapat diketahui nilai total dan rataan jumlah kejadian yang berguna untuk dasar pengambilan keputusan (Kaminsky et al., 1978 dan Montgomery, 2013).

Banyak kejadian sehari-hari yang menghasilkan data diskrit.Selain itu secara data dipilih yang berdistribusi geometrik. Contohnya banyaknya antrian pasien pada rumah sakit, banyaknya orang berbelanja pada suatu mall. Bagaimana menganalisisnya berdasarkan pengendalian kualitas dengan menggunakan grafik pengendali total dan rataan untuk variabel acak diskrit tersebut.

\section{DISTRIBUSI POISSON DAN DISTRIBUSI GEOMETRIK}

\subsection{Distribusi Poisson}

Untuk mengetahui suatu distribusi data data dari kejadian yang muncul dengan daerah definisi tipe kontinu dengan unit tertentu, dapat didekati menggunakan distribusi Poisson. Adapun definisinya sebagai berikut:

Suatu variable acak X dikatakan berdistribusi Poisson, apabila mempunyai fungsi padat peluang

$$
p(x)=\frac{e^{-\lambda} \lambda^{x}}{x !}, \quad x=0,1,2, \ldots
$$

dengan parameter $\lambda>0$.

Rataan

$$
\mu=E(X)=\sum_{x=0}^{\infty} x \frac{e^{-x} \lambda^{x}}{x !}=\lambda e^{-\lambda} \sum_{y=0}^{\infty} \frac{\lambda^{y}}{y !}=\lambda e^{0}=\lambda
$$

Ragam

$$
\sigma^{2}=V(X)=E\left(X^{2}\right)-[E(X)]^{2}=\lambda(\lambda+1)-\lambda^{2}=\lambda
$$

Karena

$$
E\left(X^{2}\right)=\sum_{x=0}^{\infty} x^{2} \frac{e^{-\lambda} \lambda^{x}}{x !}=\lambda e^{-\lambda} \sum_{x=1}^{\infty} x \frac{\lambda^{(x-1)}}{(x-1) !}=\lambda e^{-\lambda} \sum_{y=0}^{\infty}(y+1) \frac{\lambda^{y}}{y !}=\lambda(\lambda+1)
$$

Hal yang menarik dari distribusi Poisson adalah bervariabel diskrit, nilai variabel acak terkecilnya adalah sama dengan nol dan nilai rataan sama dengan nilai ragam (Bain, 1992 dan Montgomery, 2013).

\subsection{Distribusi Geometrik}

Sedangkan untuk distribusi data diskrit yang muncul dari percobaan Bernoulli sedemikian hingga banyaknya percobaan sampai muncul pertama percobaan dengan hasil sukses, dapat menggunakan konsep distribusi geometri. Adapun definisinya sebagai berikut:

Suatu variabel acak $\mathrm{X}$ dikatakan berdistribusi geometrik, apabila mempunyai Fungsi padat peluang

$$
p(x)=p(1-p)^{x-1}=p q^{x-1}, \quad x=1,2, \ldots
$$

Dengan parameter $p$ adalah peluang sukses, $q=1-p$ adalah peluang gagal, $0 \leq p \leq 1$.

Fungsi pembangkit momen

$$
M(t)=\sum_{x=1}^{\infty} e^{t x}(1-p)^{x-1} p=\frac{p}{q} q e^{t} \frac{1}{1-q e^{t}}=\frac{p e^{t}}{1-q e^{t}},
$$

dengan asumsi $q e^{t}<1$. Apabila dicari turunan pertama dan turunan kedua dari fungsi pembangkit momennya, masing-masing didapat 


$$
\begin{aligned}
M^{\prime}(t) & =\frac{p e^{t}}{\left(1-q e^{t}\right)^{2}} \\
M^{\prime \prime}(t) & =\frac{p e^{t}-p q^{2} e^{3 t}}{\left(1-q e^{t}\right)^{4}}
\end{aligned}
$$

Akibatnya mempunyai rataan

$$
\mu=E(X)=M^{\prime}(0)=\frac{p}{(1-q)^{2}}=\frac{1}{p} .
$$

Ragam

$$
\sigma^{2}=V(X)=M^{\prime \prime}(0)-\left(M^{\prime}(0)\right)^{2}=\frac{p-p q^{2}}{(1-q)^{4}}-\frac{1}{p^{2}}=\frac{q}{p^{2}}=\frac{1-p}{p^{2}}
$$

Karena

$$
E\left(X^{2}\right)=M^{\prime \prime}(0)=\frac{p-p q^{2}}{(1-q)^{4}}=\frac{1-q^{2}}{p^{3}}=\frac{1+q}{p^{2}}=\frac{2-p}{p^{2}}
$$

Hal yang menarik dari distribusi geometrik adalah bervariabel diskrit, nilai variabel acak terkecilnya adalah sama dengan satu dan nilai satu merupakan faktor dari semua bilangan bulat positif, yang mungkin terjadi pada peristiwa penjumlahan sehari-hari (Bain, 1992 dan Montgomery dan Runger, 2007).

\subsection{Uji Kecocokan Distribusi}

Menurut Daniel (1978) untuk menguji kecocokan distribusi data diskrit, dapat menggunakan uji Kolmogorov-Smirnov dengan langkah-langkahnya sebagai berikut:

1. Merumuskan hipotesis

$$
\begin{aligned}
& \mathrm{H}_{0}: F(t)=(\text { Data mengikuti distribusi penduga) } \\
& \mathrm{H}_{1}: F(t) \neq F_{0}(t) \text { (Data tidak mengikuti distribusi penduga) }
\end{aligned}
$$

2. Menentukan tingkat kesalahan

Tingkat kesalahan yang digunakan adalah sebesar 5\%

3. Statistik uji

$$
F_{0}(t) D_{n}=\sup _{-\infty<t<\infty}\left|S(t)-F_{0}(t)\right|
$$

dengan:

$F_{0}(t)$ : Distribusi kumulatif penduga

$S(t)$ : Distribusi kumulatif data sampel (terduga)

4. Kriteria pengambilan keputusan

Nilai supremum yang diperoleh dari $D_{n}$ kemudian dibandingkan dengan tabel Kolmogorov-Smirnov. Jika nilai $D_{n}$ sama dengan atau lebih besar dari nilai tabel, maka $\mathrm{H}_{0}$ ditolak. Jika tidak demikian, maka $\mathrm{H}_{0}$ diterima.

\section{HASIL DAN PEMBAHASAN}

\subsection{Penentuan Batas Kendali Grafik}

Dalam kejadian nyata dapat dijumpai suatu variabel acak diskrit yang nilai terkecilnya tidak selalu nol atau satu. Sehingga muncul variable acak X yang merupakan turunan dari distribusi geometrik, yaitu distribusi yang mempunyai:

Fungsi padat peluang, yaitu

$$
p(x)=p(1-p)^{x-1}, \quad x=a, a+1, a+2, \ldots
$$

dengan $a$ merupakan nilai terkecil banyaknya kejadian yang muncul dalam penelitian (Mitra, 1993). 
Sehingga variabel acak ini mempunyai rataan:

$$
E(X)=\sum_{x=a}^{\infty} x p(1-p)^{x-a}=p \sum_{y=1}^{\infty}(y+a-1) q^{y-1}=\frac{p}{(1-q)^{2}}+\frac{(a-1) p}{p}=\frac{1-p}{p}+a
$$

Karena distribusi ini merupakan turunan dari distribusi geometrik, maka diasumsikan bahwa keragamannya adalah sama dengan keragaman pada distribusi geometrik, yaitu Ragam:

$$
\sigma^{2}=V(X)=\frac{q}{p^{2}}=\frac{1-p}{p^{2}}
$$

Misalkan data berasal dari proses yang tersedia sebagai suatu subgroup atau sampel berukuran $n$, yang disingkat dengan $x_{1}, x_{2}, \ldots, x_{n}$. Pengamatan ini adalah pengamatan yang saling independen dan berdistribusi identik dari distribusi geometrik, dalam kondisi terkendali atau stabil. Statistik yang digunakan untuk membuat grafik pengendali adalah total banyaknya kejadian dan rataan banyaknya kejadian. Oleh sebab itu akan dibahas dua grafik pengendali berikut ini.

a. Grafik pengendali total banyaknya kejadian

Variable acak untuk total banyaknya kejadian dinyatakan dengan

$$
T=x_{1}+x_{2}+\cdots+x_{n}
$$

Sehingga variabel acak ini mempunyai rataan dan ragam, masing-masing adalah

$$
\mu_{T}=E(T)=E\left(\sum_{i=1}^{n} x_{i}\right)=\sum_{i=1}^{n} E\left(x_{i}\right)=n E(X)=n\left(\frac{1-p}{p}+a\right)
$$

Karena dianggap variabel acaknya saling bebas dan berdasarkan persamaan (15).

$$
\sigma_{T}^{2}=V(T)=V\left(\sum_{i=1}^{n} x_{i}\right)=n V(X)=\frac{n(1-p)}{p^{2}}
$$

Karena dianggap variable acaknya saling bebas dan berdasarkan persamaan (16). Menurut Kaminsky et al. (2002), grafik pengendali untuk total banyaknya kejadian dinotasikan dengan grafik G. Sehingga batas kendali grafik G dapat dimodelkan sebagai berikut:

$$
\begin{array}{ll}
\text { Batas kendali atas }(\mathrm{BKA}) & =n\left(\frac{1-p}{p}+a\right)+L \sqrt{\frac{n(1-p)}{p^{2}}} \\
\text { Garis tengah }(\mathrm{GT}) & =n\left(\frac{1-p}{p}+a\right) \\
\text { Batas kendali bawah (BKB) } & =n\left(\frac{1-p}{p}+a\right)-L \sqrt{\frac{n(1-p)}{p^{2}}}
\end{array}
$$

dengan $L$ merupakan koefisien dari simpangan baku variabel acak grafik pengendali.

Grafik pengendali ini dapat dioperasikan bilamana tersedia nilai parameter $p$ dan $a$, dengan $0<p<1$ dan nilai $a$ merupakan nilai terkecil banyaknya kejadian yang muncul dalam penelitian. Jika nilai $p$ tidak diketahui maka perlu ditaksir, Menurut Kaminsky et al. (2002)nilainya dapat didekati dengan rumus

$$
\hat{p}=\frac{1}{\overline{\bar{x}}-a+1}
$$

dengan $\overline{\bar{x}}$ adalah rataan dari semua data hasil penelitian. Selanjutnya secara teoritis misalkan terdapat $m$ subgroup (sampel) yang masing-masing berukuran $n$, dan total 
banyaknya kejadian dalam tiap-tiap sampel adalah $t_{1}, t_{2}, \ldots, t_{m}$. Maka rataan banyaknya kejadian per sampel adalah

$$
\bar{t}=\frac{t_{1}+t_{2}+\cdots+t_{m}}{m}
$$

Oleh sebab itu didapat hubungan bahwa

$$
\overline{\bar{x}}=\frac{1-\hat{p}}{\hat{p}}+a=\frac{\bar{t}}{n},
$$

berdasarkan persamaan (22) dan persamaan (23). Sedangkan berdasarkan persaman (22) dan persamaan (24) dihasilkan hubungan

$$
\frac{1-\hat{p}}{\hat{p}^{2}}=\frac{\frac{\bar{t}}{n}-a}{\hat{p}}=\left(\frac{\bar{t}}{n}-a\right)\left(\frac{\bar{t}}{n}-a+1\right)
$$

Sebagi implikasinya diperoleh batas kendali grafik $\mathrm{G}$ yang baru, yaitu

$$
\begin{array}{ll}
\text { Batas kendali atas (BKA) } & : \bar{t}+L \sqrt{n\left(\frac{\bar{t}}{n}-a\right)\left(\frac{\bar{t}}{n}-a+1\right)} \\
\text { Garis tengah (GT) } & : \bar{t} \\
\text { Batas kendali bawah (BKB) } & : \bar{t}-L \sqrt{n\left(\frac{\bar{t}}{n}-a\right)\left(\frac{\bar{t}}{n}-a+1\right)}
\end{array}
$$

b. Grafik pengendali rataan banyaknya kejadian

Variabel acak untuk rataan banyaknya kejadian dinyatakan dengan

$$
\bar{x}=\frac{x_{1}+x_{2}+\cdots+x_{n}}{n}=\frac{1}{n} \sum_{i=1}^{n} x_{i}
$$

Sehingga variabel acak ini mempunyai rataan dan ragam, masing-masing adalah

$$
\mu_{\bar{x}}=E(\bar{X})=E\left(\frac{1}{n} \sum_{i=1}^{n} x_{i}\right)=\frac{1}{n} \sum_{i=1}^{n} E\left(x_{i}\right)=E(X)=\frac{1-p}{p}+a
$$

Karena dianggap variabel acaknya saling bebas dan berdasarkan persamaan (15).

$$
{\sigma_{\bar{x}}}^{2}=V(\bar{X})=V\left(\frac{1}{n} \sum_{i=1}^{n} x_{i}\right)=\frac{1}{n^{2}} V\left(\sum_{i=1}^{n} x_{i}\right)=\frac{1}{n} V(X)=\frac{(1-p)}{n p^{2}}
$$

Karena dianggap variabel acaknya saling bebas dan berdasarkan persamaan (16).

Menurut Kaminsky et al. (2002), grafik pengendali untuk rataan banyaknya kejadian dinotasikan dengan grafik $\mathrm{H}$. Sehingga batas kendali grafik $\mathrm{H}$ dapat dimodelkan sebagai berikut:

$$
\begin{array}{ll}
\text { Batas kendali atas (BKA) } & =\frac{1-p}{p}+a+L \sqrt{\frac{1-p}{n p^{2}}} \\
\text { Garis tengah }(\mathrm{GT}) & =\frac{1-p}{p}+a \\
\text { Batas kendali bawah (BKB) } & =\frac{1-p}{p}+a-L \sqrt{\frac{1-p}{n p^{2}}}
\end{array}
$$

dengan $L$ merupakan koefisien dari simpangan baku variabel acak grafik pengendali. 
Demikian pula untuk grafik pengendali $\mathrm{H}$, jika nilai parameter $p$ tidak diketahui maka perlu ditaksir dengan nilai $\hat{p}$. Berdasarkan persamaan (24) dan persamaan (25) dihasilkan model grafik kendali $\mathrm{H}$ yang baru sebagai berikut:

$$
\begin{array}{ll}
\text { Batas kendali atas (BKA) } & : \frac{\bar{t}}{n}+\frac{L}{\sqrt{n}} \sqrt{\left(\frac{\bar{t}}{n}-a\right)\left(\frac{\bar{t}}{n}-a+1\right)} \\
\text { Garis tengah (GT) } & : \frac{\bar{t}}{n} \\
\text { Batas kendali bawah (BKB) }: \frac{\bar{t}}{n}-\frac{L}{\sqrt{n}} \sqrt{\left(\frac{\bar{t}}{n}-a\right)\left(\frac{\bar{t}}{n}-a+1\right)}
\end{array}
$$

\subsection{Analisis Grafik Pengendali Total dan Rataan Diskrit}

Berikut akan dibahas penerapan grafik pengendali $\mathrm{G}$ dan grafik pengendali $\mathrm{H}$ tentang pelayanan kepada nasabah di suatu bank pemerintah pada bagian teller. Data diambil selama 25 hari dengan jam kerja dari pukul 08.00 - 15.00. Setiap nasabah yang datang dan berhubungan dengan teller dicatat. Adapun hasil datanya disajikan pada tabel berikut ini.

Tabel 1. Banyaknya Nasabah yang Datang pada Jam Kerja

\begin{tabular}{cccccccc}
\hline Koding & \multicolumn{7}{c}{ Pukul } \\
\cline { 2 - 7 } Hari & $\mathbf{0 8 . 0 0 - 0 9 . 0 0}$ & $\mathbf{0 9 . 0 0 - 1 0 . 0 0}$ & $\mathbf{1 0 . 0 0 - 1 1 . 0 0}$ & $\mathbf{1 1 . 0 0 - 1 2 . 0 0}$ & $\mathbf{1 2 . 0 0 - 1 3 . 0 0}$ & $\mathbf{1 3 . 0 0 - 1 4 . 0 0}$ & $\mathbf{1 4 . 0 0 - 1 5 . 0 0}$ \\
\hline 1 & 11 & 8 & 7 & 7 & 17 & 1 & 1 \\
2 & 2 & 11 & 9 & 11 & 11 & 1 & 1 \\
3 & 2 & 1 & 8 & 1 & 8 & 5 & 1 \\
4 & 5 & 3 & 2 & 4 & 5 & 2 & 1 \\
5 & 6 & 13 & 2 & 2 & 13 & 5 & 3 \\
6 & 3 & 6 & 3 & 3 & 3 & 3 & 1 \\
7 & 5 & 8 & 8 & 8 & 2 & 1 & 2 \\
8 & 6 & 4 & 10 & 10 & 2 & 4 & 2 \\
9 & 3 & 6 & 2 & 6 & 1 & 1 & 1 \\
10 & 2 & 15 & 1 & 8 & 3 & 1 & 3 \\
11 & 5 & 13 & 7 & 7 & 13 & 1 & 1 \\
12 & 9 & 6 & 7 & 7 & 9 & 1 & 3 \\
13 & 3 & 7 & 6 & 6 & 3 & 3 & 1 \\
14 & 8 & 7 & 9 & 9 & 3 & 2 & 3 \\
15 & 7 & 6 & 14 & 14 & 7 & 8 & 1 \\
16 & 4 & 2 & 9 & 9 & 4 & 1 & 2 \\
17 & 3 & 11 & 1 & 1 & 1 & 2 & 1 \\
18 & 5 & 19 & 5 & 5 & 19 & 3 & 1 \\
19 & 6 & 6 & 15 & 15 & 5 & 6 & 5 \\
20 & 9 & 2 & 7 & 7 & 9 & 8 & 2 \\
21 & 14 & 7 & 5 & 5 & 6 & 10 & 6 \\
22 & 8 & 4 & 3 & 3 & 8 & 2 & 1 \\
23 & 20 & 4 & 1 & 4 & 4 & 5 & 1 \\
24 & 10 & 15 & 2 & 17 & 7 & 2 & 7 \\
25 & 11 & 2 & 15 & 3 & 15 & 2 & 3 \\
\hline
\end{tabular}

Langkah-langkah dalam penyelesaiannya adalah

Uji Distribusi Geometrik

Hipotesis: $\mathrm{H}_{0}$ : Data berdistribusi geometrik

$\mathrm{H}_{1}$ : Data tidak berdistribusi geometrik

Jika diambil tingkat kesalahan 0,05 untuk uji dua arah, didapat nilai kritis sebesar 0,103 dengan ukuran sampel 175. Untuk mendapatkan statistik uji, perlu bantuan Tabel 2 berikut. 
Tabel 2. Jumlah Kumulatif Nasabah dan Selisih Kumulatifnya

\begin{tabular}{ccccccc}
\hline $\mathbf{i}$ & $\mathbf{X}$ & $\mathbf{f}(\mathbf{x})$ & $\mathbf{J K}(\mathbf{x})$ & $\mathbf{S}(\mathbf{x})$ & $\mathbf{F}(\mathbf{x})$ & $\mathbf{D A}$ \\
\hline 1 & 1 & 29 & 29 & 0,166 & 0,176 & 0,010 \\
2 & 2 & 23 & 52 & 0,297 & 0,321 & 0,024 \\
3 & 3 & 22 & 74 & 0,423 & 0,441 & 0,018 \\
4 & 4 & 9 & 83 & 0,474 & 0,539 & 0,065 \\
5 & 5 & 14 & 97 & 0,554 & 0,620 & $\mathbf{0 , 0 6 6}$ \\
6 & 6 & 14 & 111 & 0,634 & 0,687 & 0,053 \\
7 & 7 & 15 & 126 & 0,720 & 0,742 & 0,022 \\
8 & 8 & 12 & 138 & 0,789 & 0,788 & 0,001 \\
9 & 9 & 9 & 147 & 0,840 & 0,825 & 0,015 \\
10 & 10 & 4 & 151 & 0,863 & 0,856 & 0,007 \\
11 & 11 & 6 & 157 & 0,897 & 0,881 & 0,016 \\
12 & 13 & 4 & 161 & 0,920 & 0,919 & 0,001 \\
13 & 14 & 3 & 164 & 0,937 & 0,934 & 0,004 \\
14 & 15 & 6 & 170 & 0,971 & 0,945 & 0,026 \\
15 & 17 & 2 & 172 & 0,983 & 0,963 & 0,020 \\
16 & 19 & 2 & 174 & 0,994 & 0,975 & 0,020 \\
17 & 20 & 1 & 175 & 1,000 & 0,979 & 0,021 \\
\hline
\end{tabular}

Ternyata berdasarkan olahan Tabel 2 diperoleh nilai statistik uji sebesar 0,066. Dalam hal ini berarti $\mathrm{H}_{0}$ diterima, yang artinya bahwa data berdistribusi geometrik.

Karena syarat perlu terpenuhi, maka untuk proses selanjutnya layak dilakukan. Untuk mendapatkan batas kendali dari grafik $\mathrm{G}$ dan $\mathrm{H}$, perlu dicari nilai rataan total dari sampel $\bar{t}$. Hal ini perlu tabel berikut ini:

Tabel 3. Nilai Rataan dan Total dari Banyaknya Nasabah

\begin{tabular}{cccccccccc}
\hline $\mathbf{N S}$ & $\mathbf{X}_{\mathbf{1}}$ & $\mathbf{X}_{\mathbf{2}}$ & $\mathbf{X}_{\mathbf{3}}$ & $\mathbf{X}_{\mathbf{4}}$ & $\mathbf{X}_{\mathbf{5}}$ & $\mathbf{X}_{\mathbf{6}}$ & $\mathbf{X}_{\mathbf{7}}$ & $\mathbf{X}$ & $\mathbf{T}$ \\
\hline 1 & 11 & 8 & 7 & 7 & 17 & 1 & 1 & 7,4 & 52 \\
2 & 2 & 11 & 9 & 11 & 11 & 1 & 1 & 6,6 & 46 \\
3 & 2 & 1 & 8 & 1 & 8 & 5 & 1 & 3,7 & 26 \\
4 & 5 & 3 & 2 & 4 & 5 & 2 & 1 & 3,1 & 22 \\
5 & 6 & 13 & 2 & 2 & 13 & 5 & 3 & 6,3 & 44 \\
6 & 3 & 6 & 3 & 3 & 3 & 3 & 1 & 3,1 & 22 \\
7 & 5 & 8 & 8 & 8 & 2 & 1 & 2 & 4,9 & 34 \\
8 & 6 & 4 & 10 & 10 & 2 & 4 & 2 & 5,4 & 38 \\
9 & 3 & 6 & 2 & 6 & 1 & 1 & 1 & 2,9 & 20 \\
10 & 2 & 15 & 1 & 8 & 3 & 1 & 3 & 4,7 & 33 \\
11 & 5 & 13 & 7 & 7 & 13 & 1 & 1 & 6,7 & 47 \\
12 & 9 & 6 & 7 & 7 & 9 & 1 & 3 & 6,0 & 42 \\
13 & 3 & 7 & 6 & 6 & 3 & 3 & 1 & 4,1 & 29 \\
14 & 8 & 7 & 9 & 9 & 3 & 2 & 3 & 5,9 & 41 \\
15 & 7 & 6 & 14 & 14 & 7 & 8 & 1 & 8,1 & 57 \\
16 & 4 & 2 & 9 & 9 & 4 & 1 & 2 & 4,4 & 31 \\
17 & 3 & 11 & 1 & 1 & 1 & 2 & 1 & 2,9 & 20 \\
18 & 5 & 19 & 5 & 5 & 19 & 3 & 1 & 8,1 & 57 \\
19 & 6 & 6 & 15 & 15 & 5 & 6 & 5 & 8,3 & 58 \\
20 & 9 & 2 & 7 & 7 & 9 & 8 & 2 & 6,3 & 44 \\
21 & 14 & 7 & 5 & 5 & 6 & 10 & 6 & 7,6 & 53 \\
22 & 8 & 4 & 3 & 3 & 8 & 2 & 1 & 4,1 & 29 \\
23 & 20 & 4 & 1 & 4 & 4 & 5 & 1 & 5,6 & 39 \\
24 & 10 & 15 & 2 & 17 & 7 & 2 & 7 & 8,6 & 60 \\
25 & 11 & 2 & 15 & 3 & 15 & 2 & 3 & 7,3 & 51 \\
\hline
\end{tabular}


Sehingga diperoleh nilai $\bar{t}=\frac{995}{25}=39,8$.

Berdasarkan Tabel 3 dapat diketahui bahwa nilai $a=1$ dan $n=7$. Sehingga jika diambil nilai $L=3$ batas kendali kedua grafik baik grafik $\mathrm{G}$ maupun grafik $\mathrm{H}$ dapat direalisasi beserta visualisasinya, yaitu:

- Untuk grafik kendali G

Berdasarkan persamaan (26), (27) dan (28) dihasilkan

$\mathrm{BKA}=80,77$

$\mathrm{GT}=39,8$

$\mathrm{BKB}=0$

Adapun gambarnya sebagai berikut:

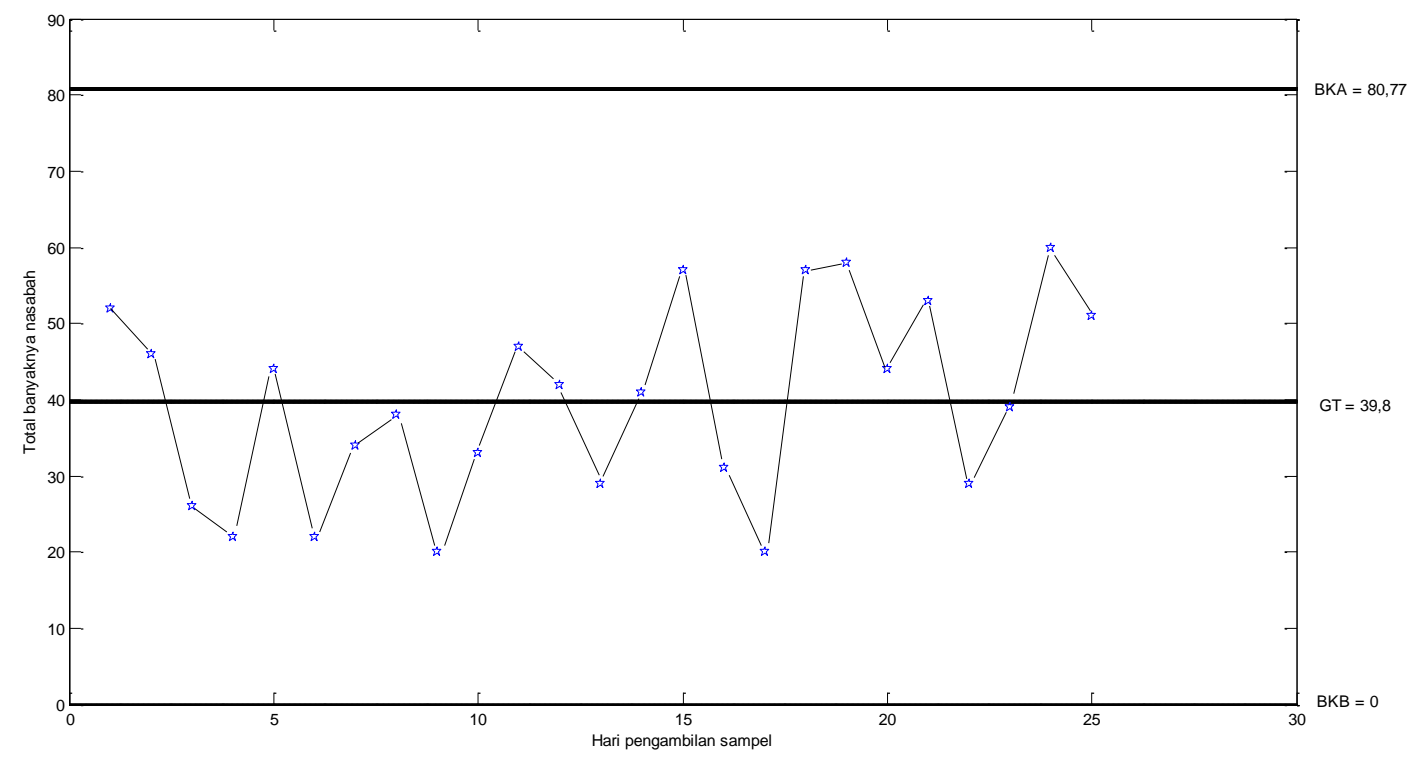

Gambar 1. Grafik Pengendali Total Banyaknya Nasabah

Berdasarkan Tabel 3 dan Gambar 1, terlihat bahwa semua titik sampel berada di dalam batas kendali. Sehingga proses dinyatakan terkendali.

- Untuk grafik kendali $\mathrm{H}$

Berdasarkan persamaan (34), (35) dan (36) dihasilkan

$\mathrm{BKA}=11,54$

$\mathrm{GT}=5,8$

$\mathrm{BKB}=0$

Adapun gambarnya sebagai berikut: 


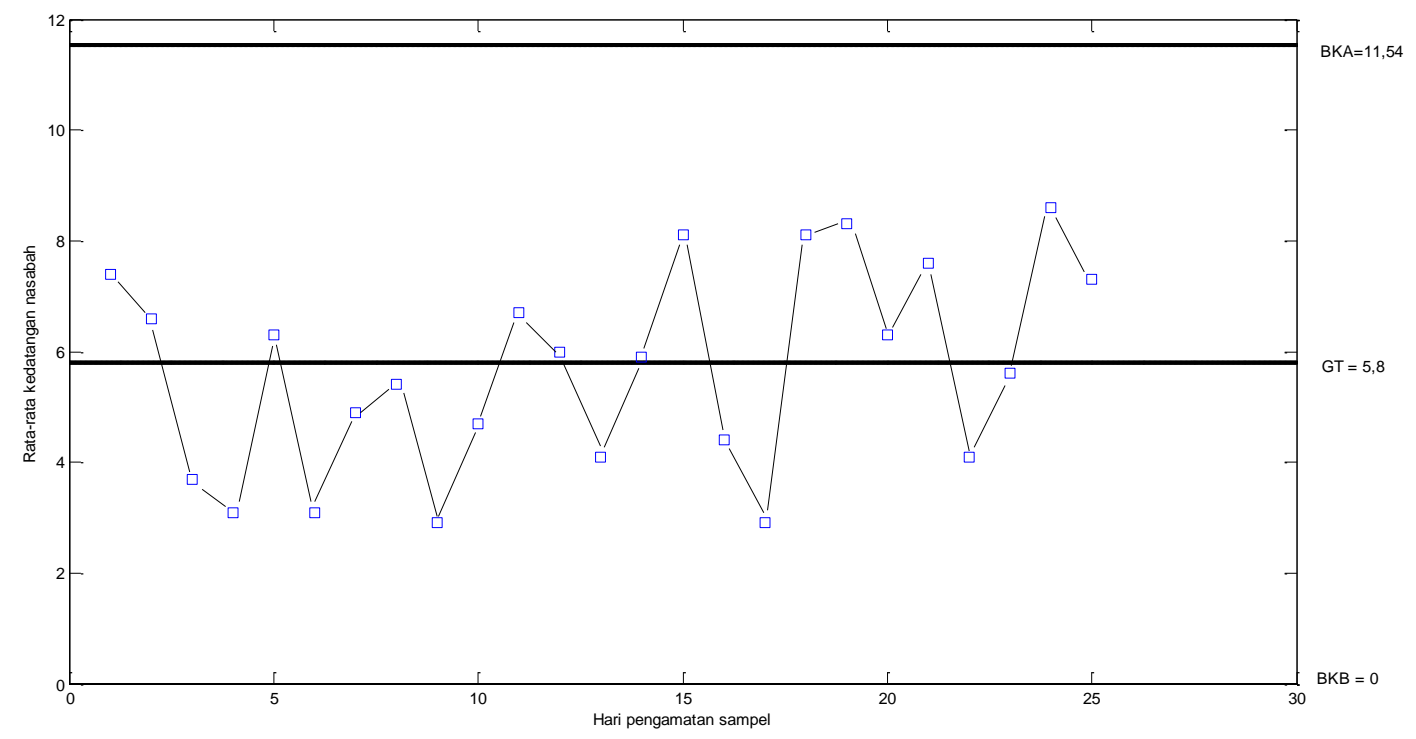

Gambar 2. Grafik Pengendali Rataan Banyaknya Nasabah

Berdasarkan Tabel 3 dan Gambar 2, terlihat bahwa semua titik sampel berada di dalam batas kendali. Sehingga proses dinyatakan terkendali atau stabil.

\section{KESIMPULAN}

Grafik pengendali total kejadian dan grafik pengendali rata-rata kejadian dapat digunakan apabila kejadiannya merupakan kelompok diskrit, datanya berdistibusi geometrik dan juga merupakan fungsi dari waktu/periode. Konstruksi kejadian yang dibuat adalah jumlah total kejadian dan ratannya dalam periode/waktu yang diselidiki.

Berdasarkan grafik pengendali total kejadian, informasi yang didapat adalah maksimal jumlah keseluruhan nasabah yang datang setiap hari adalah 81 orang, rataratanya setiap hari adalah 40 orang. Sedangkan menurut grafik pengendali rattan kejadian, informasi yang didapat adalah maksimal rata-rata nasabah yang datang setiap hari adalah 5 orang, rata-ratanya setiap hari adalah 6 orang. Dengan diketahui nilai kuantitatif baik dari jumlah total maupun rata-rata kedatangan nasabah setiap harinya, instansi/perusahaan akan dapat memprediksi kejadian yang muncul. Sehingga diharapkan tidak muncul permasalahan, karena sudah diantisipasi.

\section{DAFTAR PUSTAKA}

Bain, L.J. 1992.Introduction to Probability and Mathematical Statistics, Second Edition.California.Duxbury Press.

Chapra, S.C.2008.Applied Numerical Methods with MATLAB for Enginers and Scientists, Second Edition.New York.McGraw-Hill, Inc.

Daniel, W. 1978.Statistika Nonparametrik Terapan.Jakarta.Gramedia.

Kaminsky, F.C., Benneyan, J.C., Davis, R.D., and Burke, R.J. 2002,Statistical Control Charts Based on A Geometric Distribution.Journal of Quality Technology, Vol. 24, pp 63-69.

Ho, L.L. and Quinino, R.C. 2013.An Attribute Control Chart for Monitoring TheVariability of a Process.International Journal Production Economics, Vol. 145, Issue 1, pp 263-267. 
Mathew, J.H. and Fink, K.D. 2004.Numerical Methods Using MATLAB,Fourth Edition. New Jersey. Pearson Prentice Hall, Inc.

Mitra, A. 1993.Fundamentals of Quality Control and Improvement. New York.Macmillan Publishing Company.

Montgomery, D.C.2013.Statistical Quality Control, Seventh Edition.New York.John Wiley \& Sons, Inc.

Montgomery, D.C. and Runger, G.C.2007.Applied Statistics and Probability for Engineers, Fourth Edition.New York.John Wiley \& Sons, Inc.

More, H.2007.MATLAB for Engineers.New Jersey.Pearson Prentice Hall, Inc.

Sudarno.2014. Grafik Pengendali Ragam Sampel untuk Monitoring Variabilitas Proses Produksi.Media Statistika, Vol. 7, No. 1, pp $11-19$.

Wu, Z., Khoo, M.B.C., Shu, L., and Jiang, W. 2009.An np Control Chart for Monitoring The Mean of A Variable Based on An Attribute Inspection.International Journal of Production Economic, 121, pp 141 - 147. 